№3 2020

DOI:

UDC: $13: 316.64: 316.334 .4(043.5$

Oleg Maltsev

multiple Ph.D (psychology, philosophy), Academician of the Ukrainian Academy of Sciences,

Head of the Memory Institute

Odessa, Ukraine

E-mail: kbsp613@gmail.com

ORCID: 0000-0002-8589-6541

\title{
HISTORICAL BACKGROUND OF THE KILLER PSYCHOMODEL: PRAXEOLOGICAL ANALYSIS
}

The problem of the identity of the offender (the one who attacks, robs and $\mid$ or murders) is one of the most complex in criminology. The individual is a key element of crime in general and of a specific crime in particular, since it has subjective causes which, when they interact with the environment, lead to the commission of the crime. If it comes to killing contract, whether it's for hire or money, it's more complicated than that.

The purpose of the following scientific exploration is to represent a systematic review of the socio-historical background of so-called killer psychomodel - the phenomenon yet neither revealed, nor scientifically thoroughly researched.

One of the innovative approaches to developing this psychomodel is that the killer (or hired assassin) is praxeologically viewed from a professional perspective (i.e., who is killer regarding 'killer' as a profession). Ontological analysis of the 'killer' phenomenon is provided regarding the philosophical dispositions of such a person, the psychological background of such an individual, his specific living conditions, the special conditions created by the organizers aiming these people to continue their 'killer' routine activities throughout their lives.

Keywords: psychomodel, prototypology, criminology, memory studies, killer as a profession, killer, psychological portrait.

Анотація. Мальцев О.В. Історична довідка психомоделі вбивці: праксеологічний аналіз.

Проблема аналізу ідентності кривдника, тобто людини яка здійснює певні насильницькі дії, є однією з найбільш комплексних завдань в системі досліджень кримінології. Індивідуум є ключовою складовою злочину як такого, а також злочину за певною класифікацією, в силу існування комплексу причин, які у моменти взаємодії індивіда з навколишнім світом, призводять до скоєння насильницьких дій. Найскладнішими з точки зору осмислення когнітивного досвіду виступають випадки залякування або вбивства, здійснених за своєрідним контрактом між замовником злочину і насильником-виконавцем. 
Метою нашої розвідки є репрезентація системного аналізу соціально-історичного фону і передумов формування психологічної моделі так званого «найманого вбивці».

Одним з інноващійних підходів до розуміння історичних стадій формування такої психомоделі найманого вбивці стає осмислення практики насилля як професійної діяльності. Онтологічний підхід до розуміння явища «найманого вбивці» забезпечується за допомогою аналізу світоглядних диспозицій такої людини, психологічного фону формування схильності до насильницьких дій індивідуума, його специфічних умов виховання та ситуативного життєвого простору. Умови функціонування зазначеного простору активно підтримуються зацікавленими у результатах злочинної діяльності замовниками і організаторами з метою закріплення та максимального подовження існування шаблонних форм такої життєдіяльністі індивідуума задля підтримки його «професії» найманого вбивці.

Ключові слова: психомодель, прототипологія, кримінологія, дослідження пам'яті, найманий вбивця як «професія», кілер, психологічний портрет.

\section{Relevance of the research topic}

A degraded loser, a bitter loner, obsessive compulsive, and prone to violence, is seen as a hired assassin. But none of this has anything to do with reality. Praxeological understanding is relevant in the study of demythologization of the phenomenon of personal development such as a killer. The media, the cinema, individual experts in their fields have put a lot of effort into creating a stereotypical pattern of what this killer, a contract killer understood as a post-Soviet, European or US citizen looks like. These are three different stereotypes, although their organizational structure, manners, and handwriting are the same, even though their views are different.

According to the research plans in 2020, the monograph «Psychological portrait of the hired killer» for the first time will represent psychomodel of the killer, providing for all mental, historical, sociocultural changes, And the main thing that directly describes the genesis of personality transformation before the emergence of such a category as «mercenary killer».

An absolutely important is the fact that before this scientific challenge, there was no single methodological base of research that would allow us to study the psychomodel of the killer and describe it practically. Directly, the methodological apparatus was developed under the direction of Dr Oleg Maltsev, which made it possible to carry out high-precision investigations of the peculiarities of the killer's personality, his psychomotor reactions, motives and prevailing psychological reactions, motor patterns and so on.

\section{Analysis of recent research and publications}

A particular value in the research work carried out is the method of scientific research that has been developed and can rightly be described as innovative. We owe the appearance of this methodology to the founder of the school of destiny Lipot Szondi, his pupil and follower Martin Achtnich, one of the world-renowned masters of 
deep psychology Karl Gustav Jung, as well as the legendary Soviet scientist, academics Gregory Popov and Alexey Yakovlev. Without the contributions of these scientists, it would not have been possible to create a workable psychological machine laid down in the foundation of the psychological profile of the killer.

To begin with, the significant point to note is that the killer's profession running without orders (demand in the unfair competition market, for example) is not relevant. To conclude, if there's no customer, there's no killer. And from that fact, a lot of criminology problems raise - the ones directly related to psychology. The killer cannot act on his own: someone must supply him with orders (contracts to murder the chosen victim). Hence, such activity goes rather dangerous, since everyone is covering and hiding his interests right at the moment of contact. The most important aspect is that there is no warranty of successful performance.

The killer phenomenon, among others, is based on specialized skills, and, consequently, any special skills require training.

\section{Presentation of the main materials of the study}

Every time it comes to killer's contract and the killer's actions, we are dealing with an organized military group that needs to be trained or that is already trained. The most plausible film about killers, in the view of the author, is the series «Time of Cruelty». In the first days of the democracy in Russian Federation, the fate of many counter-intelligence and police officers was tragically crashed, since not all of them could withstand moral pressure and the sharp condemnation of these services by the media and much of society. Many, having forgotten their oath and duty, left military service and entered the criminal business - the secret arms trade, involving the military in such tasks has been and remains a central concern.

From the point of view of prototypology, it should be noted that at different times the image of the killer was formed and illuminated by different sources in different forms. The media, cinema, fiction, and individual experts in their fields have put a lot of effort into creating a stereotypical pattern of what a contract killer looks like, as understood by a post-Soviet citizen, a European or US citizen. These are three different stereotypes, although their organizational structure, manners, and handwriting are the same, even though their views are different.

The peculiar note is, I was taking an experiment by asking different people the following question: «Could you, please, ask yourself, what image comes to your mind if you hear the phrase «hired murderer» or «killer»?

This experiment from a viewpoint psychological highlitened the following: most often, the killer - is a sole man, a character wearing black clothes (i.e., that matters), he takes the cover or organises an ambush somewhere in the attic of a multi-storey apartment with a sniper rifle. I think it's very important to point out that this stereotype is a colossal delusion. No 'single killer' acts in real life. A 'killer' is a group job, acting in a city, doing risky complex job, almost impossible to be accomplished alone. Organizing the killing group requires trained performers on the one hand, and managing the whole pieces on the other. Therefore, much attention is paid in research 
to the direct demiphology of the phenomenon of personal development such as the hired killer.

Mercenaries or killer's activity is a specific element of the criminal tradition. It should be taken for granted that without professional killers there is no criminal tradition. Mercenary murder was widely represented in Venice, in France («Notre Dame de Paris»), in a country where assassins stood at the very top of the criminal hierarchy. And I'll give you the earliest example. In the 16th century, you literally had to get a lot of attention to write about you. A whole book has been written about «Beati Paoli» organization.

Legend reveals, the society «Beati Paoli» was founded in the 12th century in Palermo. It was founded by 10 young aristocrats who vowed to fight against any form of arbitrariness. They would gather at night and decide who to punish. The Black Book read the sins of a person (usually an official or a feud cooperating with the occupation regime. Sicily, due to its geographic location, was constantly occupied by plenty of external conquerors. The loop, the arrow, the bullet, the poisoned dagger all these variations of the use of the murder weapon were somehow used by killers in this historical area/ The occupiers called the members «Beati Paoli» bandits, and the Sicilians themselves - «Men of Honour».

Also significant is the fact that the psychomodel of the killer takes into account the so-called features of the mentality - that is, the amendments dictated by historical genesis and prototypology. In a monograph covering an international sample of over 1,050 people (!), the reader does not simply know who the killer is, how he differs from other murderers, what are the psychological characteristics of the individual, but also about the effects of the amendment on regions such as Italy, Southern Africa, the US, Mexico, Spain, the territories of the post-Soviet space. The Killer is an international phenomenon that is truly dangerous to the security of the lives and activities of citizens of all States in the world. For this reason, the characteristics of the phenomenon must be taken into account in the creation of a psychological profile, that it would also be useful to form a common understanding of the killer's psychomodel and would in the future contribute directly to the work of law enforcement officials from all countries.

The research objectives are as follows:

The psychological foundations of the concept of «killer»;

The multiplying effect of the misleading about the category «hired assassin»;

Martin Achtnich concept and «killer» as a profession;

The world concept of the «killer»: the effect of the amendment on regions (Italy, USA, Spain, South Africa, Ukraine, etc. countries);

The psychological problem of being bound with a weapon;

Psychological mechanism of phenomenon «killer»;

Myths of hired killers and the demythologization of the phenomenon;

Causes, psychological history of development of the «killer» phenomenon;

Psychomodel of a killer; 
Peculiarities of the killer's psychomodel with corrections to the world's criminal systems.

\section{Results and Discussions}

In 2020, together with our colleague, academician Alexander Saichin, we are planning a very difficult and intensive scientific work. We are talking about the monograph «Psychological portrait of a hired assassin», in which we will, for the first time, provide a psychological model of the personality of the formation «Hired assassin» and consider multifaceted all unconscious and conscious motives, The passions, conditions, motives, and even the demands of a changing environment that promote a change in the psyche of a person so profoundly that they embrace a special philosophy that allows them to honor killing themselves as a profession.

So, let's start with the most important thing - a phenomenon that defies trivial logic and empirical observation, is alien to a good citizen and very much in demand in a special market.

Who is the «killer»?

The phenomenon itself is relatively recent; as world history attests, in different states there are many examples and evidence of the existence of the category of «mercenary killer» (or «killer») and transformations of such category, particularly evident in an era of changes in the non-permanent and sometimes even fragile fabric of society and the State.

By studying the psychomodels of the killer, we will look at the history of the different regions and briefly acquaint ourselves with the characteristics of the criminal subcultures and their formations.

\section{SOUTH ITALY}

So, first of all, lie assume it is significant to review multicultural region of Italy, especially its southern region. Three «sisters» of organized crime in the South of Italy, known throughout the world as Mafia, Ndrangheta and Camorra, do not require presentation. However, the approach to the question of who the assassin is and what he should be (!) is quite different for these organizations.

Regarding the Mafia in its current configuration, the killer will overwhelmingly be a lone gunman. But it wasn't always like this. Initially in Palermo there was some mysterious organization of «people of honor» - Beati Paoli. It was a group of persons, not a single person. And based on all the historical data that has come to this day about Beati Paoli, the group consisted of two to four people. But with the passage of time, the Mafia was rebroadcast, its structure altered. Instead of a group of people, one person becomes a killer - a single person.

Researching the Mafia from this point, one may claim there is a tendency towards a small group, but that the model of a hired assassin for the Mafia still remains a lone individual. Moreover, the killer is one of the most respected men in the Mafia, a man of very high status. More about the retransmission of the Mafia in the course of history, its configurations, the philosophy of this southern-Italian criminal tradition can be found in my monograph «Philosophy of the South of Italy», which was written in 
the Calabria expedition on the basis of more, More than six years of research into the criminal tradition of the South of Italy.

Camorra. It is important to note that in this criminal organization behind the concept of «killer» there is a group of persons. It is a gang with varying numbers (2-5 people). An example of this is one of the most notorious crimes in Naples in recent years. Four Camorrists on two motorcycles (two were driving and two were sitting behind them with automatic rifles) shot at two police officers and wounded several officers. The reason for this crime is that the Camorrists didn't like the way the police are working at the moment. So they decided to shoot the cops. This kind of person is a real gangster. But the Camorra that the world is watching today was not what it used to be. Ta Camorra was also rebroadcast, but retained the historical prerequisites of being attracted to the group (the desire to work in the group). They used to work in detachments of 20 to 25 men in different territories.

Ndrangheta. In this criminal organization the concept of «killer» is quite complicated. As it is said, «salt» consists in that Ndrangheta is based on blood ties. This is a family form of a criminal organization, so, as far as the category of the killer is concerned, it can be any configuration.

What is the difference between the three organizations?

In Ndrangheta, one has to be a very respected, truly authoritative person to trust (!) such a task. Being a killer in an organization like this is a reward for loyalty, a reward for what he's done before. In the Mafia, being a killer is a job. In Camorra, it is revenge, a form of «response», which is realized by a criminal group of persons. In this context, there is a substantial difference between the three organizations. The killer may be one person or a group of individuals, but the approach to the category is very important - it is very different in each of these criminal structures.

From the point of view of prototypology, the Revolutionary Revolutionary Party's attitude towards the assassination was very similar to that of the Ndrangheta. Thus, the concept of the «award» is identical both for the Ndrangheta and for the personalities of the party of Essers of the pre-revolutionary kind. The terrorist organisation members even argued and quarreled over who would be honoured to take the risk, to make the attempt, i.e., who was allowed to fire.

\section{SOUTHERN AFRICA}

The South African subculture also became famous in the history of crime due to its special «hired assassins». However, this region is still more canonical. In the South African criminal tradition, which the world knows as digital (numerical) gangs, there is an entire unit of «assassins». They are known as the « 27 th», and in fact they are a gang (!) of killers. It is precisely the members of the gang of the 27 th's that only do that, that kill people as if it is their «professional specialization».

It is known, in particular, that there are three types of gangs in southern Africa: the 26th, 27th and 28th. This is a coherent system of three gangs. The 27th only kill people. This is their only course of action. There is no more. Within the organization itself, however, there are different functions, rules, training system, philosophy, code and so on. 
A killer could act alone, as well as he could be working in a group. Reviewing the criminal organizations like the Mafia, Ndrangheta, or Camorra, we conclude, the single men or small groups of individuals act as killers, but we do not see in the south of Italy an organization of killers. In the South African criminal tradition there is a whole system - a special «department of assassins \killers». This is the fundamental difference between Southern Italy and Southern Africa regions.

MEXICO AND THE UNITED STATES

From the historical point of view, Mexico is unique, at least with regard to a particular device. Mexico is roughly divided in half. In one part of the country, there is clearly a tendency towards a gang (group organization) and in the other part, towards a single person. And exactly the same configuration is functioning in the South of the USA (the South of the USA prevails a single type of activity, and the North - to «team work», to the gang). Thus, the position of the prototypology an example of this model is the film «Magnificent Seven», which very vividly shows the phenomenon of a single killer. And even if the «magnificent representatives» gather in the group, each person in it is a lone person. In the north of the United States, the film «Gangs of New York» is a striking example of such an artistic work.

\section{IMPERIAL RUSSIA}

At the beginning we will explain that it will be about Imperial Russia until 1917. So, in the environment of this state the concept of «killer» has some «strange form». The oddity and ambiguity is that as such «the killer» in the Russian Empire is not. There were some «bushes», but «bushes» was not a profession. In fact, there were no professional killers in the Russian Empire until 1917. At the level of nobility, of course, there were strings and attempts (as in Europe) to solve political problems by duel. It was present in the history of the Empire, but such a profession as «killer» - there was no such of a kind.

It should be taken for granted, the first hired killers appear in the Russian Empire within the period of the Revolutionary Revolutionary Party blossom. It is only with the emergence of these guerrilla organizations that terror and, in particular, mercenary killings become a weapon of political struggle. Therefore, initially on the territory under consideration nobody «had any desire» to search for the person who would professionally engage in «hired murders». Such a «character» is not found in Russian literature, in fairy tales or in historical documents. Accordingly, the origins of hired assassins in Tsarist Russia are Revolutionary Fighters. And, among them, there were such people who «did not hide» even the Grand Prince. They blew up the people close to the tsarist person, shot at Stolypin in the theater, killed Romanovs and many others. These people are such «feats» and the skills are not seriously famous on the whole world.

Thus, the Pteras are a combat organization, a diversionary intelligence group, built on a military model, numbering groups of three to five people. At the same time, the people of the Sirs were deeply ideologically knowledgeable. They were capable of dying on their own, but still fulfilling the mission of the organization. There were cases in which the Revolutionary Army operatives blew up the carriages with them 
and killed themselves. Another example is the shooting in Stolypin, where the killers were arrested almost instantly by the police and executed. So these people knew what they were getting into - this terrible Russian self-sacrifice that existed for the Revolutionary Party. To be sure, both the Bolshevik Party robbed and the Separators also robbed. But it was a secondary function. Their original profession was to kill.

After crossing the border of 1917, mercenary murder became a state crime. This is no longer a political matter, but a state matter. Examples of this are many (as we will do in the monograph). One of the most striking examples is the famous murder of Trotsky with an ice pick. Assassination by order became a state category, until the collapse of the Soviet Union.

\section{Conclusions}

Overall, in summing up a certain intermediate result, it is important to note that the amendment to the world concept «killer» gives not only a large-scale idea of the peculiarities of origin, roots and the method of preparation of the hired killer, but also a so-called «mental component of the killer».

Since the purpose of the represented scientific exploration is to define a systematic review of the socio-historical background of 'killer psychhomodel', we have provided the praxeological analysis of key historical regions, rich in examples of raising 'killer' phenomenon. For instance, on the basis of previous studies of the South Italian criminal tradition, it became known which approaches are characteristic of the Italian Mafia, as is done in Ndrangheta, Camorra. It should be taken for granted, since for Camorra «killer» is the most uncontrollable «substance», on the contrary, in Mafia and in Ndrangheta «killer» is a product of planned training, philosofical raising, as well as the result of skill obtaining programm.

Furthermore, a psycho-portrait of a killer is part of the specific equation. In comparison, the 'maniac' does not require any special training. That's the difference between him and a killer. The killer requires special training, otherwise his first assignment will end in prison. Because of this, the first pillar of the killer's psychoportrait is the fact that the «hired assassin» as a phenomenon requires special training, or partially special, but is not spontaneous.

Within this article the review of the historical part of current research on the psychological model of a killer (or a 'hitman', as it is classified in some English-speaking countries) has been summarized.

\section{References}

Abulhanova-Slavskaya K.A. The Strategies of Life. M.: Mysl, 1991. 299 p.

Achtnich M. BBT - Berufsbilder-Test. Projektives Verfahren zur Abklärung der Berufsneigung. Bern: Hans Huber, 1979. 368 s.

Achtnich M. Schicksalsanalytisch Orientierte Berufsberatung Anhand des BerufsbilderWahltestes. Ein Beitrag zur Psychologie der Berufswahl, des Berufswechsels und der Berufsprognose. Bericht über das 5. Kolloquium der Internat. Forschungsgemeinschaft für Schicksalspsychologie. Bern: Hans Huber, 1971. 465 s.

Bell D. The Coming of Post-Industrial Society. A Venture in Social Forecasting. N. Y.: Penguin \& Co, 1976. 265 p. 
Borisova G. Social Destruction as universal phenomenon of society life (Frankfurt School position // Bulletin of Nizhegorodskiy Universitu by N. Lobachevskiy. Social studies. 2007. https://cyberleninka.ru/article/n/sotsialnaya-destruktsiya-kak- universalnyy-fenomen-zhizni-obschestva-pozitsiya-frankfurtskoy-shkoly-2

Fromm E. Beyond the Chains of Illusion: My Encounter with Marx and Freud (1962) \M.: AST, 2010. 320 p.

Horkheimer M., Adorno T. Dialectic of Enlightenment. Philosophical Fragments. M.-SPb.: Medium, Yuventa, 1997. 312 p.

Kantor K. M. Logical sociology of Alexander Zinoviev as social philosophy // Alexander Zinoviev. M.: ROSSPEN, 2009. 385 p.

Karmanov A. M. Smart as the new post-information society development degree // Economics, statistics and informatics. №5, 2014. P. 38-41.

Critical sociology of Frankfurt school // Bulletin of the Russian university of friendship of peoples. Sociology. Ed.3, 2007. P. 52-67

Marcuse G. One-dimensional person. M.: «Refl-book», 1994. 368 p.

Pollock F. Zur Geldtheorie von Karl Marx. Inauguraldissertation. Wirtschafts- und Sozialwissenschaftliche Fakultät der Universität Frankfurt am Main [Masch.] 1923 । Nachdruck: Freiburg: Wien, 2018. S. 23-127.

Popov G.S. (1951). Phenomenology of Memory: basic methodolofical approaches to human memory research. [Manuscript. Archive „NII Pamyati“ - Arhiv NIIP (NII Pamyati) F. 3 (Fond "Nasledie akademika G. Popova", Vena 1940). Des. 2, 1951 g. D. 1. Fp.1-6. P. 41-50.

Schmidt A. Kritische Theorie, Humanismus, Aufklärung. Philosophische Arbeiten. Stuttgart: Reclam, 1981. 235 s.

Silberman M., Hansburg F. (Contributor) People Smart: Developing Your Interpersonal Intelligence. Oakland, CA: Berrett-Koehler Publishers, 2000. 276 p.

Szondi L. Ich-Analyse. Die Grundlage zur Vereinigung der Tiefenpsychologie.Teil 1. Bern: Hans Huber. 1956. 385 s.

Yudin A. The paradoxes of Great Refuse // Marcuse G. About Eros and civilization. Philosophical research of Freud's studies. Kiev, 1995. 275 p. 